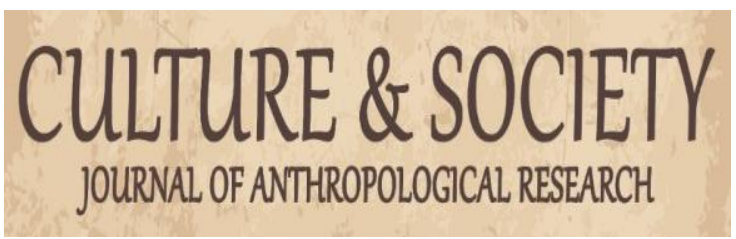

Culture \& Society: Journal of Anthropological Research VOL. 2 NO. 4 JUNI 2021

http://culture.ppj.unp.ac.id

Email: culture@ppj.unp.ac.id

ISSN: 2686-343X (E-ISSN) 2686-3421 (P-ISSN)

DOI: https://doi.org/10.24036/csjar.v2i4.82

\title{
Nilai Lokal Budaya Jawa dan Islam dalam Tinjauan Multikulturalisme
}

\author{
Siti Mustaghfiroh ${ }^{1}$, Badarudin Safe' ${ }^{2}$ \\ ${ }^{1}$ IAIN Metro, ${ }^{2}$ STIES Darul Huda \\ Email: vieroh48@gmail.com, albadar877@gmail.com
}

\begin{abstract}
Abstrak
Penelitian ini bertujuan untuk menjelaskan hubungan antara nilai lokal budaya Jawa dengan nilainilai dalam ajaran agama Islam. Penelitian ini dilakukan dengan menggunakan metode library research. Pada penelitian ini, metode analisis yang digunakan yaitu studi literatur dan mengumpulkan bahan atau data penelitian, selanjutnya data tersebut diolah dan dianalisis secara mendalam dengan pendekatan multikulturalisme. Berdasarkan kajian yang telah dilakukan menunjukkan adanya hubungan upaya masyarkat untuk mengakomodasikan antara nilai-nilai Islam dengan budaya Jawa pra-Islam. Upaya itu telah dilakukan sejak Islam mulai disebarkan oleh para mubaligh yang tergabung dalam Walisongo dan dilanjutkan oleh para pujangga kraton, serta dipraktikkan dalam kehidupan sehari-hari orang Jawa Islam. Upaya itu masih terus berproses hingga dewasa ini. Sebagian dari nilai-nilai Islam itu telah menjadi bagian dari budaya Jawa hingga saat ini. Dengan sikapnya yang demikian itu, secara tidak langsung dapat dikatakan bahwa orang Jawa adalah orang yang sudah mengimplementasikan idiologi multikulturalisme, jauh hari sebelum multikulturalisme itu dibicarakan banyak orang.
\end{abstract}

Kata kunci: Ajaran Islam, Budaya Jawa, Multikulturalisme.

\section{Abstract}

This study aims to explain the relationship between the local values of Javanese culture and the values in the teachings of Islam. This research was conducted using the library research method. In this study, the analytical method used is to study literature and collect research material or data then the data is processed and analyzed in depth with a multiculturalism approach. Based on the studies that have been done, it shows that there is a relationship between community efforts to accommodate Islamic values and pre-Islamic Javanese culture. This effort has been made since Islam began to be spread by preachers who were members of Walisongo and continued by court poets, and it is practiced in the daily life of Javanese Muslims. This effort is still in progress until today. Some of these Islamic values have become part of Javanese culture until now. With such an attitude, it can be said indirectly that the Javanese are people who have implemented the ideology of multiculturalism, long before multiculturalism was discussed by many people.

Keywords: Javanese culture, Islamic teachings, Multiculturalism.

Published: June 30, 2021

Culture \& Society: Journal of Anthropological Research Vol. 2, No. 4, Th. 2021 


\section{Pendahuluan}

Multikultural berarti beraneka ragam kebudayaan. Menurut Parsudi Suparlan (2002:10) akar kata dari multikulturalisme adalah culture (kebudayaan), yaitu kebudayaan yang dilihat dari fungsinya sebagai pedoman bagi kehidupan manusia. Dalam konteks umum, istilah multikultural ini telah membentuk suatu ideologi yang disebut multikulturalisme. Konsep multikulturalisme tidak dapat disamakan dengan konsep keanekaragaman secara sukubangsa atau kebudayaan sukubangsa yang menjadi ciri masyarakat majemuk, karena multikulturalisme menekankan keanekaragaman kebudayaan dalam kesederajatan. Multikulturalisme adalah sebuah ideologi dan sebuah alat untuk meningkatkan derajat manusia dan kemanusiaannya. Untuk dapat memahami multikulturalisme diperlukan landasan pengetahuan yang berupa bangunan konsep-konsep yang relevan dan mendukung keberadaan serta fungsi multikulturalisme dalam kehidupan manusia. Bangunan konsep-konsep ini harus dikomunikasikan di antara para ahli yang mempunyai perhatian ilmiah yang sama tentang multikulturalisme sehingga terdapat kesamaan pemahaman dan saling mendukung dalam memperjuangkan ideologi ini.

Selanjutnya Suparlan mengutip Fay (1996), Jary dan Jary (1991), Watson (2000) dan Reed (ed. 1997) menyebutkan bahwa multikulturalisme ini akan menjadi acuan utama bagi terwujudnya masyarakat multikultural, karena multikulturalisme sebagai sebuah ideologi akan mengakui dan mengagungkan perbedaan dalam kesederajatan baik secara individual maupun secara kebudayaan. Dalam model multikulturalisme ini, sebuah masyarakat (termasuk juga masyarakat bangsa seperti Indonesia) mempunyai sebuah kebudayaan yang berlaku umum dalam masyarakat tersebut yang coraknya seperti sebuah mosaik. Di dalam mosaik tercakup semua kebudayaan dari masyarakat-masyarakat yang lebih kecil yang membentuk terwujudnya masyarakat yang lebih besar, yang mempunyai kebudayaan seperti sebuah mosaik. Dengan demikian, multikulturalisme diperlukan dalam bentuk tata kehidupan masyarakat yang damai dan harmonis meskipun terdiri dari beraneka ragam latar belakang kebudayan.

Berdasarkan pemahaman multikulturalisme tersebut, dalam penelitiaan ini akan diulas tentang kebudayaan Jawa dalam hubungannya dengan nilai-nilai agama, yakni Islam. Orang Jawa dengan sikapnya yang ramah terhadap segala macam perbedaan budaya yang masuk, secara tidak langsung sudah menunjukan bahwa orang-orang Jawa memiliki penghargaan yang besar terhadap terhadap paham multikulturalisme. Bahkan jika dilihat dari sisi sejarah, orang Jawa itu sudah menerapkan paham multikulturalisme dalam bentuk penggabungan berbagai macam budaya, jauh hari sebelum idiologi multikulturalisme itu dibicarakan banyak orang, seperti sekarang ini. Untuk mengetahui tentang adanya pengakuan orang jawa terhadap idiologi multikulturalisme, di bawah ini akan dibicarakan panjang lebar tentang budaya Jawa dalam kaitannya dengan nilai-nilai agama dan kebudayaan asing (di luar Jawa/Arab).

Sementara itu, beberapa artikel jurnal yang sudah mengkaji tentang multikulturalisme antara lain telah dilakukan oleh Azizah, Lutfiatul \& Purjiatin Azhar (2015) dengan judul "Islam di Tengah Masyarakat Multikultural Indonesia (Studi atas Konsep Multikultural Abdul Aziz Sahedina)": Jurnal Toleransi; Suparlan, P (2002). "Menuju Masyarakat Indonesia yang Multikultural": Junal Antropolgi Indonesia; Quway, Nabila (2018). "Integrasi Multikultural dalam Masyarakat Multietnis (Jawa, Cina, dan Arab) di Kota Semarang" : Jurnal Ijtimaiya; Tahir, Masnun (2017). "Menjadi Muslim di Negara Multikultural: Dinamika, Tantangan, dan strategi dalam persepektif Fikih Multikultural": Jurnal Al'Adalah; Irhadayaningsih, Ana (2012). "Kajian Filosofis terahadap Multikulturalisme Indonesia": Jurnal Humanika; dan Munif, Afandi (2018). "Potret Masyarakat Multikultural di Indonesia": Jurnal Multikultural.

Beberapa artikel yang disebutkan di atas, secara keseluruhan membahas tentang paham multikulturalisme, tetapi secara spesifik tidak membahas multikulturalisme dalam kaitannya dengan nilai lokal budaya Jawa dan Islam. Dengan demikian kajian tentang nilai lokal budaya Jawa dan Islam dengan sudut pandang multikulturalisme masih layak dilakukan. Sementara itu,

Culture \& Society: Journal of Anthropological Research Vol. 2, No. 4, Th. 2021 
kajian yang sudah pernah dilakukan oleh peneliti sebelumnya akan dijadikan bahan rujukan sekaligus sebagai pembanding dalam penelitian ini.

\section{Metode Penelitian}

Penyusunan artikel ini dilakukan menggunakan metode library research. Pengumpulan data penelitian dengan metode library research dilakukan dengan memanfaatkan sumber dan bahan kepustakaan. Metode ini tidak menggunakan penelitian lapangan dikarenakan batasan kegiatannya hanya berhubungan dengan data-data kepustakaan berupa literatur buku dan artikel jurnal yang berkaitan dengan tema penelitian.

Buku yang menjadi data primer dalam penelitian ini adalah buku yang berjudul Abangan, Santri, Priyayi dalam masyarakat Jawa karya Clifford Geertz (1981), Kebudayaan Jawa karya Koentjoraningrat dan Mistisisme Jawa: Ideologi Di Indonesia karya Niels Mulder (2001). Sedangkan artikel jurnal yang menjadi data primer dalam penelitian ini adalah yang ditulis oleh Azizah, Lutfiatul \& Purjiatin Azhar (2015) dengan judul "Islam di Tengah Masyarakat Multikultural Indonesia (Studi atas Konsep Multikultural Abdul Aziz Sahedina)", Suparlan, P (2002). "Menuju Masyarakat Indonesia yang Multikultural", Quway, Nabila (2018). "Integrasi Multikultural dalam Masyarakat Multietnis (Jawa, Cina, dan Arab) di Kota Semarang", Tahir, Masnun (2017). "Menjadi Muslim di Negara Multikultural: Dinamika, Tantangan, dan strategi dalam persepektif Fikih Multikultural", Irhadayaningsih, Ana (2012). "Kajian Filosofis terahadap Multikulturalisme Indonesia" dan Munif, Afandi (2018). "Potret Masyarakat Multikultural di Indonesia" (Azizah \& Azhar, 2015) (Suparlan, 2002) (Quway, 2018) (Tahir, 2017) (Irhadayaningsih, 2012) (Afandi, 2018). Sementara itu, buku dan artikel lain yang masih relevan dengan penelitian ini akan dijadikan sumber data sekunder. Beberapa sumber rujukan tersebut akan dianalisis secara mendalam dengan pendekatan multikulturalisme.

\section{Hasil dan Pembahasan}

\section{Proses Penyebaran Agama Islam di Jawa}

Dalam proses penyebaran Islam di Jawa terdapat dua pendekatan tentang bagaimana cara yang ditempuh agar nilai-nilai Islam diserap menjadi bagian dari budaya Jawa. Pendekatan yang pertama disebut Islamisasi Kultur Jawa. Melalui pendekatan ini budaya Jawa diupayakan agar tampak bercorak Islam, baik secara formal maupun secara substansial. Upaya ini ditandai dengan penggunaan istilah-istilah Islam, nama-nama Islam, pengambilan peran tokoh Islam pada berbagai cerita lama, sampai kepada penerapan hukum-hukum, norma-norma Islam dalam berbagai aspek kehidupan. Adapun pendekatan yang kedua disebut Jawanisasi Islam, yang diartikan sebagai upaya penginternalisasian nilai-nilai Islam melalui cara penyusupan ke dalam budaya Jawa. Melalui cara pertama, Islamisasi dimulai dari aspek formal terlebih dahulu sehingga simbol-simbol keislaman nampak secara nyata dalam budaya Jawa, sedangkan pada cara kedua, meskipun istilah dan nama-nama Jawa tetap dipakai, tetapi nilai-nilai yang dikandungnya nilai-nilai Islam sehingga Islam menjadi men-Jawa. Berbagai kenyataan menunjukan bahwa produk-produk budaya orang Jawa yang beragama Islam cenderung mengarah kepada polarisasi Islam kejawan atau Jawa yang keislaman sehingga timbul istilah Islam Jawa atau Islam Kejawen. Sebagai contoh pada nama-nama orang banyak dipakai nama seperti Abdul Rahman, Abdul Rozak, meskipun orang Jawa menyebutnya Durahman, Durajak, dan lain-lain. Begitu juga penggunaan sebutan Jawa Narimo Ing Pandum yang pada hakikatnya merupakan penerjemahan dari istilah Islam tawakkal sebagai konsep sufistik. Dalam fiqh terdapat konsep sepikul-segendongan sebagai bentuk implementasi pembagian harta waris dari konsep Islam, perbandingan 1:2 bagi anak laki-laki dengan anak perempuan. Demikian juga bentuk fisik tempat ibadah Islam (masjid) masih mengacu kepada bangunan tempat ibadah agama terdahulu (Hindu), dan masih banyak contoh yang lain (Tahir, 2017).

Culture \& Society: Journal of Anthropological Research Vol. 2, No. 4, Th. 2021 
Sebagai suatu cara pendekatan dalam proses alkulturasi, kedua kecenderungan ini merupakan strategi yang sering diambil ketika dua kebudayaan saling bertemu. Apalagi pendekatan itu sesuai dengan watak orang Jawa yang cenderung bersikap moderat serta mengutamakan keselarasan. Namun, persoalan dan bahan perbincangan di kalangan para pengamat adalah makna yang terkandung dari percampuran dua kebudayaan itu. Mereka memiliki penilaian yang berbeda ketika dimensi keberagaman orang Islam Jawa termanisfestasikan dalam kehidupan sehari-hari. Sebagian mereka menilai bahwa percampuran itu masih sebatas pada segi-segi lahiriah sehingga Islam seakan hanya kulitnya saja sehingga nilai-nilai esensialnya adalah Jawa. Sementara itu, sebagian yang lain menilai sebaliknya, dalam arti nilai Islam telah menjadi semacam ruh dari penampakan budaya Jawa kendatipun secara konkret tidak berlabel Islam (Mulder, 2001).

Tampaknya tradisi menyelaraskan antara Islam dan budaya Jawa ini telah berlangsung sejak awal perkembangan Islam di Jawa. Beberapa literatur karya sastra pujangga Jawa pada pertengahan abad 19 seperti Dewa Ruci karya R.Ng. Yasadipura, Serat Wirid Hidayat Jati karya R.Ng. Ranggawarsita, Wedhatama karya Mangkunegara IV, dan lain-lain juga mencerminkan upaya-upaya seperti itu. Dalam kehidupan keberagaman, kecenderungan untuk mengakomodasikan Islam dengan budaya Jawa setempat telah melahirkan kepercayaankepercayaan serta upacara-upacara ritual sebagaimana akan diuraikan pada bagian bertikut ini. Adapun yang dimaksud dengan budaya Jawa di sini adalah budaya yang bersumberkan dari ajaran-ajaran agama Hindu dan Budha yang bercampur aduk dengan kepercayaan animism (Mulder, 2001).

\section{Hubungan Antara Budaya Jawa dan Islam dalam Aspek Kepercayaan}

Setiap agama dalam arti seluas-luasnya tentu memiliki aspek fundamental, yakni aspek kepercayaan terhadap suatu yang sakral, yang suci, atau yang gaib. Dalam Islam aspek fundamental itu terumuskan dalam istilah akidah atau keimanan sehingga terdapatlah rukun iman, yang di dalamnya terangkum hal-hal yang harus dipercayai atau diimani oleh seorang muslim. Yang termasuk dalam rukun iman adalah percaya kepada Allah, para malaikat-Nya, para nabi-Nya, kitab-kitab-Nya, hari akhir (hari kianat, surga dan neraka), dan percaya kepada qadla dan qadar, yakni ketentuan tentang nasib baik atau buruk dari Allah swt. Unsur-unsur keimanan itu karena berjumlah enam disebut dengan rukun iman yang enam. Namun demikian, di luar semua itu masih terdapat keimanan-keimanan yang lain yang juga harus dipercayai seperti percaya kepada adanya setan, iblis, syafa'at Nabi Muhammad saw. dan lain-lain.

Sementara itu, dalam budaya Jawa pra Islam yang bersumberkan dari ajaran agama seperti Hindu terdapat kepercayaan tentang adanya para Dewata seperti Dewa Brahma, Dewa Wisnu, dan Dewa Siwa, serta masih banyak lagi para dewa. Demikian juga terdapat kepercayaan terhadap kitab-kitab suci, orang-orang suci (para Resi), roh-roh jahat, lingkaran penderitaan (samsara), hukum karma, dan hidup abadi (moksa). Pada agama Budha terdapat kepercayaan tentang empat kasunyatan (kebenaran abadi), yakni dukha (penderitaan), samudaya (sebab penderitaan), nirodha (pemadaman keinginan), dan marga (jalan kelepasan). Kelepasan yang dimaksud adalah Nirwana, dan untuk sampai ke Nirwana harus menempuh delapan jalan kebenaran, semacam rukun iman juga dalam agama Budha. Meskpun semula agama ini tidak jelas konsep ketuhanannya, tetapi dalam perkembangannya agama Budha juga percaya kepada tuhan yang disebut Sang Hyang Adi Budha. Dari Sang Hyang Adi Budha memanifestasikan diri dalam berbagai tingkatan Budha sehingga terdapat Budha Surga. Demikian juga Budha dunia (Manusyi Budha) seperti Budha Gautama selaku penganjur agama ini (Hadiwijono, 1971). Adapun pada agama "primitif" sebagai "agama" orang Jawa sebelum kedatangan agama Hindu ataupun Budha, inti kepercayaannya adalah percaya kepada daya-daya kekuatan gaib yang menempati pada setiap benda (dinamisme), serta percaya kepada roh-roh ataupun makhluk-

Culture \& Society: Journal of Anthropological Research Vol. 2, No. 4, Th. 2021 
makhluk halus yang menempati pada suatu benda ataupun berpindah-pindah dari suatu tempat ke tempat lain, baik benda hidup maupun benda mati (animisme) (Honig, 1966).

Pada aspek ketuhanan, prinsip ajaran tauhid Islam telah berkelindan dengan berbagai unsur keyakinan Hindu-Budha maupun kepercayaan primitif. Sebutan Allah dengan berbagai nama yang terhimpun dalam asmaul husna telah berubah menjadi Gusti Allah, Gusti Kang Murbeng Dumadi (al-Khaliq), Ingnkang Maha Kuwaos (Al-Qodir), Ingkang Maha Esa (al-Ahad), Ingkang Maha Suci, dan lain-lain. Nama-nama itu bercampur dengan nama dari agama lain sehingga muncul Hyang Maha Agung (Allahu Akbar), Hyang Widi, Hyang Jagad Nata (Allah Rabb al-alamin) atau Sang Hyang Maha Luhur (Allah Ta'ala). Kata Hyang berarti tuhan atau lebih tepatnya dewa, sehingga ka-hyang-an diartikan sebagai tempat para dewa. Namun demikian, dari berbagai nama itu, dalam kehidupan sehari-hari orang Jawa lebih terbiasa dengan menyebut Gusti Allah, sehingga orang Jawa sudah terbiasa mengucap bismillah ketika akan memulai pekerjaan apapun yang baik. Demikian juga ucapan Ya Allah Gusti ketika berdoa, astagfirullah ketika merasa kecewa, dan lain sebagainya. Dalam hal ini Allah terhayati sebagai peribadi yang menjadikan, memelihara, memberikan petunjuk, dan memberi rizki kepada semua mahluk ciptaan-Nya. Namun, penghayatan tentang prinsip tauhid itu akan berbeda tatkala pemahaman tentang ketuhanan itu masuk dalam dimensi mistik bercorak pantheistik. Terdapatlah sebutan Hidup (Urip), Suksma, sehingga tuhan Allah disebut Hyang Maha Hidup, Sukma Kawakes yang mengandaikan bahwa Tuhan sebagai Dzat Yang Maha Hidup, yang menghidupi segala alam. Di dalam agama Islam Allah disebut juga al-Hayyu (Yang Hidup). Esensi dari segala yang ada itu adalah Hidup itu sendiri. Penghayatan mistik semacam itu tidak hanya terdapat dalam ajaran agama Hindu, tetapi juga ada pada tasawuf yang bercorak heterodoks sehingga di dalam mistik Jawa keduanya bertemu.

Berkaitan dengan sisa-sisa kepercayaan animisme dan dinamisme, kepercayaan mengesankan Allah itu sering menjadi tidak murni oleh karena tercampur dengan penuhanan terhadap benda-benda yang dianggap keramat, baik benda mati maupun benda hidup. Arti keramat, disini bukan hanya sekedar berarti mulia, terhormat, tetapi memiliki daya magis, sebagai sesuatu yang sakral bersifat Illahiyah. Dalam tradisi Jawa terdapat berbagai jenis barang yang dikeramatkan. Ada yang disebut azimat, pusaka, dalam bentuk tombak, keris, ikat kepala, cincin, batu akik, dan lain-lain. Barang-arang peninggalan para Raja Jawa yang disebut benda pusaka dan diberi sebutan "kyai", pada umumnya dipandang sebagai benda-benda keramat. Manusia hewan, dan tumbuh-tumbuhan tertentu dipandang sebagai sesuatu suci, keramat dan bertuah. Begitu juga kuburan-kuburan ataupun petilasan-petilasan, hari-hari tertentu, dipandang memiliki barokah atau juga dapat membawa kesialan. Barang-barang, benda-benda, orang-orang keramat itu dipandang sebagai penghubung (wasilah) dengan Allah. Oleh karena itu, bacaan doadoa tertentu berubah menjadi mantra, ayat-ayat suci al-Qur'an atau huruf-huruf Arab menjadi Rajahan yang diyakini memiliki nilai yang sangat berarti, bukan dari makna yang terkandung di dalam ayat-ayat itu melainkan dari daya gaibnya. Demikian juga al-Qur'an tidak dibaca, dipahami, dihayati arti dan maknanya sebagai petunjuk hidup yang diberikan Allah kepada manusia, tetapi dipandang sebagai azimat. Kepercayaan seperti itu terutama diperlakukan terhadap al-qur'an cetakan kecil yang dikenal dengan sebutan al-Qur'n Stambul (Istambul) (Geertz, 1981).

Kaitannya dengan ketentuan (takdir) baik ataupun buruk dari Tuhan, dalam budaya Jawa tampaknya telah terpengaruh oleh teologi Jabariyyah sehingga orang lebih cenderung bersikap pasrah, sumarah, dan narimo ing pandum terhadap ketentuan-ketentuan yang telah digariskan oleh Allah. Meskipun demikian manusia juga diberi peluang untuk beriktiar dengan kemampuan yang dimiliki, setidak-tidaknya dengan berdoa, memohon pertolongan kepada-Nya. Namun, terdapat pula upaya-upaya ikhtiari yang lebih diwarnai oleh nilai-nilai yang bersumber dari kepercayaan primitif maupun yang bersumber dari agama Hindu. Tempat-tempat yang baik, hari, bulan, dan tahun yang membawa pada nasib baik itu perlu dicari dan ditentukan dengan cara-cara magis. Hari-hari yang jelek sering disebut sebagai hari na'as. Dan pada hari na'as ini

Culture \& Society: Journal of Anthropological Research Vol. 2, No. 4, Th. 2021 
sebaiknya orang tidak melakukan kegiatan-kegiatan perayaan pesta pernikahan, melakukan perjalanan jauh, transaksi dagang dan lain-lain. Perhitungan-perhitungan magis dengan melihat neptu dari hari dan pasaran menurut rumus-rumus tertentu sangat menolong untuk mencari dan menentuka hari baik, bulan baik, serta menghindari hari-hari na'as. Tapi jika hari na'as itu keluarga yang masih hidup sehingga suatu saat arwah itu nyambangi datang ke kediaman anak keturunannnya. Roh-roh yang baik yang bukan roh nenek moyang atau kerabat disebut dhanyang, bahurekso, atau seng ngemong. Dhanyang ini dipandang sebagai roh yang menjaga dan mengawasi seluruh masyarakat desa. Dari sinilah kemudian timbul upacara bersih desa, termasuk membersihkan makam-makam disertai dengan kenduren maupun sesaji, dengan maksud agar sang dhayang akan selalu memberikan perlindungan. Di sisi lain atas dasar kepercayaan Islam bahwa orang yang meninggal dunia perlu dikirimi doa, maka ada tradisi kirim dongo (doa), tahlilan tujuh hari, empat puluh hari, seratus hari, satu tahun (mendhak), dan seribu hari (nyewu) setelah seseorang meninggal dunia. Doa kepada orang yang meninggal dunia merupakan anjuran menurut ajaran Islam, sedangkan penentuan hari-hari sebagai saat pelaksanaan upacara kirim doa lebih diwarnai oleh warisan budaya Jawa pra-Islam (Subagya, 1981).

Keyakinan tentang adanya para rasul dan nabi sebagai orang-orang yang dipilih Allah menjadi utusannya adalah merupakan salah satu bagian dari rukun iman. Dalam al-Quran setidaknya terdapat 25 rasul yang harus diimani, sejak dari nabi Adam as., sampai nabi Muhammad saw. Sebagai utusan Allah apalagi mereka dibekali oleh-Nya mu'jizat untuk mengukuhkan kerasulan mereka, maka tidak mengherankan jika mereka dipandang sebagai manusia yang luar baisa. Pada kenyataannya mereka memiliki kemampuan di luar kemampuan manusia pada umumnya. Tampaknya kepercayaan kepada nabi telah mempengaruhi keyakinan orang Jawa lama. Nama nabi Adam telah dihubungkan sedemikian rupa dengan nama beberapa dewa. Dalam silsilah raja-raja Jawa meneurut penuturan Babad Tanah Jawi dinyatakan bahwa bahwa asal-usul raja Jawa adalah keturunan nabi Adam yang menurunkan nabi Sis. Seterusnya Nabi Sis berputera Nur Cahya. Nurcahyua berputera Nurasa. Nurasa berputera Sanghyang Wening. Sanghyang Wening berputera Sanghyang Tunggal, dang Sanghyang Tunggal berputera Batara Guru. Batara Guru berputera lima orang, yakni Batara Samba, Batara Brahma, Batara Maha Dewa, dan Batara Wisnu. Batara Wisnu itulah yang menjadi raja di pulau Jawa (Olthof, 2011).

Beberapa nama nabi pun dikaitkan dengan doa-doa tertentu yang dipandang memiliki nilai khusus. Terdapat salah satu doa yang disebut doa nabi Sleman (Sulaiman) untuk mendapatkan kewaskiytaan dan keprabawaan. Ada pula doa nabi Ibrahim untuk menghindari bahaya fitnah, pencurian, kebakaran, kedatangan musuh, dihindarkan dari penyakit, dan cepat membayar hutang. Demikian juga terdapat salah satu doa nabi Yusuf yang apabila dibaca seratus kali, maka yang melihatnya akan merasa belas kasihan (Noerdaya, 1994).

Beberapa nama nabi juga dikaitkan dengan kepercayaan orang Jawa tentang hari-hari atau bulan na'as. Pada hari-hari saat na'asnya nabi, orang Jawa tidak boleh mantu, seperti tanggal 13 bulan Sura, (na'asnya nabi Ibrahim yang dibakar oleh raja Namrud), pada tanggal 3 bulan Maulud (na'asnya nabi Adam diturunkan ke dunia), tanggal 16 Rabiulakhir (na'asnya nabi Yusuf tatkala dimasukan ke dalam sumur), tanggal 5 Jumadilawal (na'asnya nabi Nuh yang dilannda banjir), tanggal 24 Dzulkaidah (na'asnya nabi Yunus tatkala dimakan ikan Hiu). Para wali yang dipandang sebagai pewaris para nabi juga dipandang memiliki kemampuan luar biasa, tidak hanya ketika mereka masih hidup, tetapi juga sesudah mereka meninggal dunia. Oleh karena itu, terdapat suatu tradisi ngalap berkah di kalangan orang Jawa ketika mereka berziarah ke makam para Walisongo yang memang dalam kenyataan sejarah para wali ini merupakan tokoh-tokoh yang berjasa dalam penyebaran agama Islam di Jawa. Keyakinan tentang wasilah untuk menghubungkan doa permohonan kepada tuhan, tidak saja dikaitkan dengan para Nabi, khususnya Nabi Muhammad, tetapi juga dengan para wali (Noerdaya, 1994).

Culture \& Society: Journal of Anthropological Research Vol. 2, No. 4, Th. 2021 


\section{Hubungan antara budaya Jawa dan Islam dalam aspek Ritual}

Agama Islam hadir untuk menciptakan masyarakat yang religius dalam hubungan sosial dengan sesama makhluk ciptaan Allah. Ajaran Islam sangat memperhatikan bagaimana manusia berhubungan antara satu dengan lainnya yang disebut dengan habl min al-nas. Sedangkan hubungan manusia dengan Allah disebut juga dengan habl min Allah. Berangkat dari hubungan inilah Islam ingin membimbing kebiasaan-kebiasaan atau budaya Islam menjadi hubungan yang harmonis dengan budaya Jawa (Azizah \& Azhar, 2015).

Agama Islam mengajarkan agar para pemeluknya melakukan kegiatan-kegiatan ritualistik tertentu. Yang dimaksud dengan kegiatan ritualistik adalah meliputi berbagai bentuk ibadah sebagaimana yang tersimpul dalam rukun iman, yakni syahadat, shalat, puasa, zakat, dan haji. Khusus mengenai shalat dan puasa, di samping terdapat shalat wajib lima waktu dan puasa wajib di bulan ramadhan, terdapat pula shalat-shalat dan puasa-puasa sunah. Intisari dari shalat adalah doa, oleh karena arti harfiah shalat juga doa yang ditujukan kepada Allah swt. sedangkan puasa adalah bentuk pengendalian nafsu dalam rangka penyucian jiwa. Aspek doa dan puasa memebrikan pengaruh yang sangat luas, mewarnai berbagai bentuk upacara tradisional orang Jawa (Mulder, 2001).

Bagi orang Jawa, hidup ini penuh dengan upacara, baik upacara-upacara yang berkaitan dengan lingkaran hidup manusia sejak dari keberadaannya dalam perut ibu, lahir kanak-kanak, remaja, dewasa sampai saat dengan kematiannya, atau juga upacara-upacara yang berkaitan dengan kehidupan sehari-hari dalam mencari nafkah, khususnya bagi para petani, pedagang nelayan, dan upacara-upacara yang berhubungan dengan tempat tinggal, seperti membangun gedung untuk berbagai keperluan, membangun dan meresmikan tempat tinggal, pindah rumah dan sebagainya. Upacara-upacara itu semula dilakukan untuk menangkal pengaruh buruk dari daya kekuatan gaib yang tidak dikehendaki yang akan membahayakan bagi kelangsungan hidup manusia. Dalam kepercayaan lama, upacara dilakukan dengan mangadakan semacam sesaji atau kurban yang disajikan kepada daya-daya gaib (roh-roh, makhluk-makhluk halus, dewadewa) tertentu. Tentu dengan upacara itu, harapan pelaku upacara adalah agar hidup senantiasa dalam keadaan selamat (Mulder, 2001).

Secara luwes Islam memberikan warna baru pada upacara-upacara itu dengan sebutan kenduren atau selametan. Di dalam upacara selametan ini yang pokok adalah pembacaan doa (donga) yang dipimpin oleh orang yang dipandang memiliki pengetahuan tentang Islam. Apakah seorang modin, kaum, lebe, atau kiai selain itu, terdapat seperangkat makanan yang dihidangkan kepada peserta selamatan, serta makanan yang dibawa pulang ke rumah masing-masing peserta selamatan, yang disebut sebagai berkat. Makanan-makanan itu disediakan oleh penyelanggara upacara atau sering disebut dengan shahibul hajat. Dalam bbentuknya yang khas, makanan ini adalah nasi tumpeng, ingkung ayam, dan ditambah umburampe yang lain. Jumlah undangan selametan disesuaikan dengan tingkat pentingnya selametan tersebut serta tingkat kemampuan ekonomi shahibul hajat. Namun demikian diutamakan para tetangga sekitar.

Dengan pola inti serupa itulah, nilai-nilai Islam telah merasuki pelaksanaan upacaraupacara selametan dalam berbagai bentuknya. Geertz, demikian juga Koentjaraningrat telah mengemukakan berbagai upacara yang dilakukan oleh orang Jawa (Geertz, 1981).

Berkaitan dengan lingkaran hidup terdapat berbagai jenis upacara, antara lain:

1. Upacara tingkeban atau mitoni, dilakukan pada saat janin berusia tujuh bulan dalam perut ibu. Dalam tradisi santri, pada upacara tingkeban ini seperti yang dilakukan di daerah Bagelan dibacakan nyanyian berjanjen dengan alat musik tamburin kecil. Nyanyian ini dibawakan empat orang dan dihadapan mereka duduk sekitar 12 orang yang turut bernyanyi. Nyanyian perjanjen ini sebenarnya merupakan riwayat Nabi Muhamad yang bersumber dari kitab Barzanji (Geertz, 1981).

2. Upacara kelahiran, dilakukan pada saat anak diberi nama dan pemotongan rambut (bercukur) pada saat bayi berumur tujuh hari atau sepasar. Karena itu, upacara ini disebut juga upacara 
nyepasari. Dalam tradisi Islam santri, upacara ini disebut upacara korban aqiqah yang diucapkan dalam lidah Jawa kekah. Ditandai dengan penyembelihan hewan aqiqah berupa dua ekor kambing untuk anak laki-laki dan satu ekor kambing untuk anak perempuan (Geertz, 1981).

3. Upacara sunatan, dilakukan pada saat anak laki-laki dikhitan. Namun pada usia mana anak itu dikhitan, pada berbagai masyarakat pelaksanaannya berbeda-beda. Ada yang melaksanakannya antara usia empat sampai delapan tahun, dan pada masyarakat yang lain dilaksananakan tatkala anak berusia antara 12-14 tahun. Pelaksanaan khitan ini sebagai bentuk perwujudan secara nyata tentang pelaksanaan hokum Islam. Sunatan atau khitanan ini merupakan pernnyataan pengukuhan sebagai orang Islam. Karena itu seringkali sunatan disebut selam sehingga mengkhitankan disebut menyelamaken, yang mengandung makna mengislamkan (ngislamaken) (Geertz, 1981).

4. Upacara perkawinan, dilakukan pada saat pasangan muda-mudi akan memasuki jenjang berumah tangga. Upacara ini ditandai secara khas dengan pelaksanaan syariat Islam yakni aqad nikah (ijab qabul) yang dilakukan oleh pihak wali mempelai wanita dengan pihak mempelai pria dan disaksikan oleh dua orang saksi. Slametan yang dilakukan berkaitan dengan upacara perkawinan ini sering dilaksanakan dalam beberapa tahap, yakni pada tahap sebelum akad nikah, pada tahap akad nikah dan tahap sesudah akad nikah (ngundhuh manten, resepsi pengantin). Antara upacara akad nikah dengan resepsi, dari segi waktu pelaksnaannya, dapat secara berurutan atau secara terpisah. Jika terpisah, maka dimungkinkan dilakukan beberapa kali upacara selametan, seperti pada saat ngundhuh manten, pembukaan dhuwe gawe ditandai dengan selametan nggelar klasa, dan pada saat mengakhirinya dilakukan slametan mbalik klasa (Geertz, 1981).

5. Upacara kematian, pada saat mempersiapkan penguburan orang mati yang ditandai dengan memandikan, mengkafani, menshalati, dan pada akhirnya menguburkan. Setelah selesai penguburan itu selama sepekan, tiap malam hari diadakan selametan mitung dina (tujuh hari), yaitu kirim doa dengan didahului bacaan tasbih, tahmid, tahlil, dan shalawat nabi yang secara keseluruhan rangkaian bacaan itu disebut tahlilan. Istilah tahlil itu sendiri berarti membaca dzikir dengan bacaan laa ilaaha illallaah. Slametan yang sama dilakukan pada saat kematian itu sudah mencapai 40 hari (matang puluh), 100 hari (nyatus), satu tahun (mendhak sepisan), dua tahun (mendhak pindo), dan tiga tahun (nyewu). Tahlilan kirim doa kepada leluhur terkadang dilakukan juga keluarga secara bersama-sama pada saat-saat ziarah kubur, khususnya pada waktu menjelang bulan Ramadhan. Upacara ziarah kubur ini disebut upacara nyadran. Dewasa ini bacaan tahlilan lebih meluas penggunaannya. Tahlil tidak hanya dibaca sebagai upaya mendoakan ahli kubur, tetapi tahlil dibaca juga sebagai pelengkap dari doa selametan sehingga kapan saja diadakan upacara slametan dimungkinkan juga untuk dibacakan tahlilan. Misalnya pada waktu mau pindah rumah, syukuran sembuh dari sakit, naik pangkat, mau berangkat dan pulang dari perjalanan jauh seperti naik haji dan lain sebagainya (Geertz, 1981).

Bentuk upacara lain, selain berkaitan dengan lingkaran hidup manusia, terdapat pula upacara yang berkaitan dengan kekeramatan bulan-bulan hijriah seperti upacara bakda besar, suran, mbubar suran, saparan, dina wekasan muludan, jumadilawalan, jumadilakhiran, rejeban (mikhraban), ngruwah (megengen), maleman riyayan, sawalan (kupatan), sela, dan sedekahan haji (Koentjaraningrat, 1984).

Sementara itu masih banyak lagi jenis upacara tahunan, yaitu upacara yang dilakukan sekali dalam setahun. Termasuk dalam upacara ini adalah upacara peringatan hari lahinya nabi Muhamad saw, tanggal 12 rabiul awal, disebut muludan. Berkenaan dengan muludan ini di beberapa kraton Yogyakarta pesta sekaten dan upacara garebeg mulud. Upacara ini terdapat di masjid dan halaan masjid kraton Yogyakarta, Surakarta, dan Cirebon. Pada upacara ini dimankan seperangkat alat musik gamelan sejak dari jam empat pagi hingga 12 malam tanpa

Culture \& Society: Journal of Anthropological Research Vol. 2, No. 4, Th. 2021 
henti, dan menjadi tontonan orang-orang yang datang dari beragai pelosok desa maupun kota. Pada malam 11 mulud, Sultan Yogyakarta dan Sunan Surakarta yang diiringi oleh para pembesar keraton dan pengawal keraton masing-masing berjalan dalam suatu prosesi menuju masjid untuk melakukan sembahyang, mendengarkan khotbah, dan akhirnya makan bersama. Puncak dari perayaan sekaten ini adalah saat dibagikan makanan keramat yang dinamakan gunungan kepada rakyat, yang terdiri atas 10 sampai 12 tumpeng raksasa, masing-masing tigginya dua meter dengan hiasan indah yang terdiri dari umburampenya. Konon semula acara ini merupakan kreasi dari para wali sebagai media dakwah dalam upaya menarik orang Jawa masuk Islam. Kata sekaten berasal dari syahadatain, dua kalimat syahadat yang diucapkan sebagai tanda persaksian bahwa seseorang dinyatakan sebagai pemeluk agama Islam (Koentjaraningrat, 1984).

Selain muludan, juga teradapat upacara rejeban atau mi'radan dalam rangka memperingati peristiwa isra' mi'raj Nabi Muhammad saw. pada tanggal 27 Rajab. Kemudan juga ada upacara nisfu sya'ban pada pertengahan bulan sya'ban (ruwah) dan upacara ruwahan pada tnggal 29 ruwah, dimana sepekan sebelum bulan puasa (ramadhan) orang mengunjungi makam para leluhur atau nyadran. Pada bulan Syawal tanggal satu, orang Islam Jawa tanpa terkecuali mengadakan selamatan Idul Fitri, demikian juga pada hari ketujuh sebagai hari raya ketupat yang juga disebut syawalan. Di beberapa daerah dirayakan pesta syawalan, seperti yang dilakukan oleh masyarakat Kaliwungu, semarang, dan masyarakat krapyak Pekalongan. Pada bulan Dzulhijah atau besar terdapat perayaan Idul Adha dengan upacara penyembelihan hewan kurban. Dan menyongsong hari raya Idul Adha juga terdapat upacara grebeg besar semacam sekaten sebagaimana yang dilaksanakan di masjid Demak dan makam sunan Kalijaga di Kadilangu (Koentjaraningrat, 1984).

Ibadah puasa sebagaimana yang disyariatkan Islam telah mewarnai pula perilaku orang Jawa, yakni sebagai bentuk penyucian rohani untuk melengkapi doa-doa yang dipanjatkan kepada Tuhan. Puasa dalam Islam disebut dengan istilah siyam atau shaum, dan kata siyam ini juga dipakai dalam ungkapan bahasa Jawa halus ketika orang Jawa meng-kramakan puasa. Dalam keadaan tertentu ketika seseorang mempunyai suatu cita-cita, agar cita-cita tersebut tercapai, maka di samping ia berdoa ia juga melakukan puasa. Terdapat kebiasaan di antara orang Jawa untuk melakukan puasa pada hari Senin dan Kamis, serta puasa sunah yang lain, kendati pun kewajiban-kewajiban shalat lima waktu tidak dikerjakan. Puasa ini sering juga disebut tirakat, yakni meninggalkan makan dan minum pada hari-hari tertentu, bahkan tirakat juga diartikan tidak tidur (jaga) semalam suntuk. Meskipun demikian jika dilihat dari segi arti harfiah tirakat ini sesungguhnya berasal dari konsep Islam, yakni taraka, yang berarti meninggalkan. Dalam konteks Islam puasa maka taraka mempunyai arti yang tidak berbeda dengan siyam atau shaum (Koentjaraningrat, 1984).

\section{Kesimpulan}

Uraian tentang hubungan antara budaya Jawa dan Islam dalam aspek kepercayaan dan ritual di atas menunjukan secara jelas, baik tersurat maupun tersirat, secara langsung maupun tidak lansung, bahwa memang telah terjadi dalam kehidupan keberagaman orang Jawa suatu upaya untuk mengakomodasikan antara nilai-nilai Islam dengan budaya Jawa pra-Islam. Upaya itu telah dilakukan sejak Islam mulai disebarkan oleh para mubaligh yang tergabung dalam Walisongo dan dilanjutkan oleh para pujangga kraton, serta dipraktikkan dalam kehidupan sehari-hari orang Jawa Islam. Upaya itu masih terus berproses hingga dewasa ini. Sebagian dari nilai-nilai Islam itu telah menjadi bagian dari budaya Jawa, kendatipun di sana sini warisan nilai-nilai budaya pra-Islam masih tampak meski dalam wadah yang kelihatannya Islami. Dengan sikapnya yang demikian itu, secara tidak langsung dapat dikatakan bahwa orang Jawa adalah orang yang sudah mengimplementasikan idiologi multikulturalisme, jauh hari sebelum multikulturalisme itu dibicarakan banyak orang.

Culture \& Society: Journal of Anthropological Research Vol. 2, No. 4, Th. 2021 


\section{Daftar Pustaka}

Afandi, M. (2018). Potret Masyarakat Multikulturalisme di Indonesia. Jurnal Multikultural Universitas Yudharta Pasuruan, 2(1), 22-31.

Azizah, L., \& Azhar, P. (2015). Islam di Tengah Masyarakat Multikultural Indonesia (Studi atas Konsep Multikultural Abdul Aziz Sahedina). Jurnal Toleransi: Media Komunikasi Umat Beragama, 7(1), 74-89.

Geertz, C. (1981). Abangan, Santri, Priyayi dalam masyarakat Jawa. Jakarta: Penerbit Pustaka Jaya. Hadiwijono, H. (1971). Agama Hindu dan Agama Budha. Jakarta: Badan Penerbit Kristen.

Honig, H. (1966). Ilmu Agama I. Jakarta: Badan Penerbit Kristen.

Irhadayaningsih, A. (2012). Kajian Filosofis Terhadap Multikulturalisme Indonesia. Jurnal Humanika Undip, 15(9), 22-29.

Koentjaraningrat, K. (1984). Kebudayaan Jawa. Jakarta: Balai Pustaka.

Mulder, N. (2001). Mistisisme Jawa: Ideologi di Indonesia. Yogayakarta: LKIS.

Noerdaya, S. W. S. (1994). Kitab Primbon Atassadur Adammakna. Jakarta: Soemodidjojo Maha Dewa.

Olthof, W. L. (2011). Babad Tanah Jawi: Mulai Dari Nabi Adam Sampai Tahun 1647. Yogayakarta: Penerbit Narasi.

Quway, N. (2018). Integrasi Multikultural Dalam Masyarakat Multietnis: Strategi Akulturasi Masyarakat Etnis Jawa, Cina, dan Arab Keturunan di Wilayah Semarang. Jurnal Ijtimaiya, 2(1), $1-10$.

Subagya, R. (1981). Agama Asli Indonesia. Jakarta: Sinar Harapan dan Yayasan Cipta Loka Caraka.

Suparlan, P. (2002). Menuju Masyarakat Indonesia yang Multikultural. Jurnal Antropologi Indonesia, 69(1), 98-105.

Tahir, M. (2017). Menjadi Muslim di Negara Multikultural: Dinamika, Tantangan dan Strategi dalam Perspektif Fikih Multikultural. Jurnal Al-'Adalah, 14(2), 263-290. 